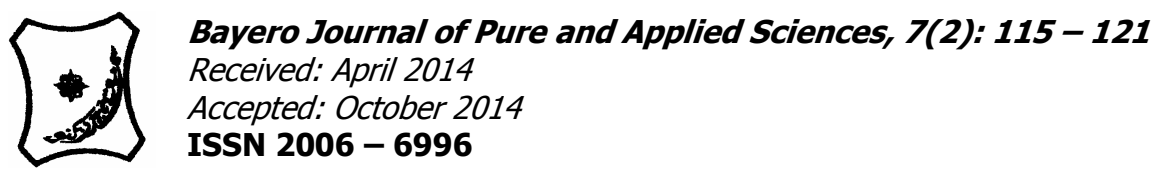

\title{
QUANTITATIVE LEACHING OF A NIGERIAN CHALCOPYRITE ORE BY NITRIC ACID
}

\author{
Alafara, A. Baba ${ }^{1+}$, Kuranga I. Ayinla ${ }^{1,2+}$, Rafiu B. Bale ${ }^{3}$ and Folahan A. Adekola ${ }^{1}$ \\ ${ }^{1}$ Department of Industrial Chemistry, University of Ilorin, P.M.B. 1515, Ilorin-24003, Nigeria. \\ ${ }^{2}$ Department of Science Laboratory Technology, Institute of Applied Sciences, Kwara State Polytechnic, \\ P.M.B. 1375, Ilorin-24009, Nigeria. \\ ${ }^{3}$ Department of Geology and Mineral Sciences, University of Ilorin, P.M.B. 1515, Ilorin-24003, Nigeria. \\ ${ }^{+}$Correspondence author: alafara@unilorin.edu.ng
}

\begin{abstract}
Due to increasing uses of copper nitrate, $\mathrm{Cu}\left(\mathrm{NO}_{3}\right)_{2}$, as catalysts, textile and polishing agents for other metals, experiment on the leaching of a Nigerian chalcopyrite ore by nitric acid for possible production of copper nitrate was examined. The effects of acid concentration, temperature and particle size on the dissolution rates of chalcopyrite ore have been investigated. Distribution of elements, compounds present within the ore particle size $-90+75 \mu \mathrm{m}$ was initially determined by $X$-ray Fluorescence (XRF), X-ray Diffraction (XRD) and Scanning Electron Microscopy (SEM) to provide basis for explaining the dissolution process. It was observed that dissolution rates were greatly affected by acid concentration, temperature and particle diameter. Kinetic data analysis showed that the dissolution mechanism followed diffusion as the rate controlling step. The reaction order was calculated to be 0.51 while the activation energy was deduced to be $29.99 \mathrm{kJmol}^{1} \mathrm{from}^{\mathrm{m}}$ the dissolution data. The $X$-ray diffraction analysis of the unleached residue at optimal leaching showed that it contains a-quartz $\left(a-\mathrm{SiO}_{2}\right)$ and Tin oxide $\left(\mathrm{SnO}_{2}\right)$.

Keywords: Chalcopyrite ore, Nitric Acid, Leaching, Dissolution Kinetics, Copper Nitrate.
\end{abstract}

INTRODUCTION

Chalcopyrite $\left(\mathrm{CuFeS}_{2}\right)$ is a sulphide mineral that derived from Greek words "chalkos", copper and pyrites known as "strike fire" (Szymanowski, 1996). It is the most common copper bearing mineral ever known, occur in igneous and metamorphic rocks and in any metalliferous vein (McGraw-Hill, 1987). Large, well shaped crystals of chalcopyrite are widely available and deposited across the globe such as England, Akita, Ugo in Japan, Zacatecas Mexico and in other places around the world. The French Greek mine in Chester co. Pennyslvania has produced huge crystal, many distorted and highly tarnished chalcopyrite (Rotuska and Chmielewski, 2008). However, chalcopyrite is often contaminated by a variety of other trace elements such as $\mathrm{Co}, \mathrm{Ni}, \mathrm{Mn}, \mathrm{Zn}$ and $\mathrm{Sn}$ substituting for $\mathrm{Cu}, \mathrm{Fe}$, Se and $\mathrm{As}$ substitute for sulfur and trace amount of $\mathrm{Ag}, \mathrm{Au}, \mathrm{Pb}$ and $\mathrm{Sb}$ as reported. It is likely many of these elements are present in finely inter-grown mineral within the chalcopyrite ore (Louise, 2008).

Due to the decline in the world deposit of high grade ores, attention has been drawn to lowgrade complex sulphide ore thereby given room to the ore processing by conventional hydrometallurgical alternatives. Hydrometallurgical processes are suitable for lean and complex ore, as processing of ores containing large amount of gangue at high temperature demands high energy and thus, creates problem of slag disposal and evolution of gaseous pollutants to the environment (Olubambi et al. 2006; Habashi, 2002; Ghosh and Ray, 1991). It has been used for copper recovery for more than 300 years. The most important development in copper hydrometallurgy, with respect to the growing number of its application as well as its future potential, has been solvent extraction. This has been the great achievement that revolutionized copper compound production all over the world and enabled to introduce hydrometallurgy for industrial scale (Szymanowski, 1996). It is evident that leaching is an important operation during solvent extraction of copper prior to its beneficiation (Baba et al. 2013).

During leaching process, different leaching media are applied (Ikiz, et al. 2006). These leachant include hydrochloric acid, sulfuric acid, ferric chloride, nitric acid, as well as other available oxidants. Thus, due to high oxidizing capacity, nitric acid often preferred among the aforementioned leachants. Therefore, the establishment of physicochemical conditions for leaching Nigerian chalcopyrite ore by nitric acid, aimed at predicting conditions for possible production of $\mathrm{Cu}\left(\mathrm{NO}_{3}\right)_{2}$ was the focus of this investigation. The $\mathrm{Cu}\left(\mathrm{NO}_{3}\right)_{2}$ is a valuable compound with varieties of application such as catalyst, textile and polishing agents for other metals as well as in the chemical voltaic cell reactions.

\section{MATERIALS AND METHODS}

Materials/Instrumentation

The chalcopyrite mineral used for this study was sourced from Akiri village, Awe Local Government of Nasarawa State, Nigeria. The ore was crushed, grounded and sieve to obtain particle size fractions: ($90+75 \mu \mathrm{m},-112+90$ and $-300+112 \mu \mathrm{m})$. All experiment were performed with particle sizes: $-90+$ $75 \mu \mathrm{m}$ unless otherwise stated. 
Characterizations of chalcopyrite ore before and after leaching at optimal conditions were carried out using X-ray fluorescence (XRF, Philips model 120454/3), Xray diffraction (XRD, Philip PW 1800) and Scanning electron microscopic techniques (JEOL JSM-6510). Nitric acid used was BDH analytical reagent grade and doubly distilled water was used in the preparation of all solutions.

\section{Leaching Procedure}

The solution was investigated in a $250 \mathrm{ml}$ glass reactor equipped with a mechanical stirrer. The reactor was filled with acid solution which was heated to the desired temperature on introduction of $10 \mathrm{~g} / \mathrm{L}$ of the ore to the reactor (Aydogan et al. 2005; Baba et al. 2009, 2012). The leaching of chalcopyrite ore with $\mathrm{HNO}_{3}$ at different concentration ranges $(0.1-8.42 \mathrm{M})$ were examined at various time up to 120 minutes. The concentration of $\mathrm{HNO}_{3}$ which gave the maximum dissolution (4M) was subsequently used for the optimization of other leaching parameters such as reaction temperature (Experimental conditions: $\mathrm{HNO}_{3}$ concentration $=4 \mathrm{M}$, Particle size $=-90+75 \mu \mathrm{m}$, Solid/liquid ratio $=10 \mathrm{~g} / \mathrm{L}$ by moderate stirring) and particle size (Experimental conditions: $\mathrm{HNO}_{3}$ concentration $=4 \mathrm{M}$, Temperature $=80^{\circ} \mathrm{C}$, Solid/liquid ratio $=10 \mathrm{~g} / \mathrm{L}$ by moderate stirring). Energy of activation, $E_{a}$, and other constants were determined from the Arrhenius plots. In all experiments, the fraction of the ore dissolved was evaluated from the initial difference in weight of the amount dissolved or undissolved at various time intervals up to 2 hours after oven drying at about $60^{\circ} \mathrm{C}$. The residue at optimal leaching $\left(80^{\circ} \mathrm{C}, 4 \mathrm{M} \mathrm{HNO}_{3}\right.$ for 2 hours) was analyzed by XRD and SEM techniques.

\section{RESULTS AND DISCUSSION}

The elemental composition of the chalcopyrite ore under study examined by XRF technique showed that the ore contains $24.16 \% \mathrm{Cu}, 36.53 \% \mathrm{Fe}$ and $2.02 \%$ $\mathrm{Mn}$ as major elements. Other elements found in the ore include $\mathrm{Sn}, \mathrm{Mg}, \mathrm{Pb}$ and $\mathrm{Ca}$. These were recorded at low to trace levels (Ayinla, 2012).

The ore phase characterized by X-ray diffractogram revealed the presence of typical lean copper which is composed by majority of oxide minerals. The phases were identified using Joint Committee on Powder Diffraction Standard File number (in curl brackets). The compounds present in the ore include: (1) $\mathrm{CuFeS}_{2}$ (chalcopyrite) $\{24-0211\}$; (2) $\mathrm{Cu}_{0.47} \mathrm{Fe}_{0.58} \mathrm{~S}_{2}$ (Fukuchilite) $\{17-0137\}$, (3) $\mathrm{Fe}_{2} \mathrm{O}_{3}$ (hematite) $\{024-0072\}$ and (4) $\mathrm{FeS}_{2}$ (pyrite) $\rightarrow$ pyrohytite $\left(\mathrm{Fe}_{7} \mathrm{~S}_{8}\right)\{22-1220\}$. These are the major compounds detected. Other phases include: (5) $\mathrm{SnO}_{2}$ (cassiterite) $\{21-1250\}$; (6) $\mathrm{SiO}_{2}$ (a-quartz) \{050490\}; (7) Galena (PbS); \{05-0792\}; (8) $\mathrm{CaCO}_{3} \cdot \mathrm{MgCO}_{3} \quad$ (dolomite) $\{05-0490\}$ and (9) Hausmannite $\left(\mathrm{Mn}_{3} \mathrm{O}_{4}\right)$ \{24-07340\}. It is important to note that the compounds (5) to (9) occurred in low to trace levels (Ayinla, 2012; Baba et al. 2013).

The effect of $\mathrm{HNO}_{3}$ concentration on the fraction of chalcopyrite ore dissolved using particle size $-90+75 \mu \mathrm{m}$ at $55^{\circ} \mathrm{C}$ was investigated at $\mathrm{HNO}_{3}$ concentration ranges $0.1 \mathrm{M}-8.42 \mathrm{M}$. The plot of fraction $(\alpha)$ dissolved as a function of leaching time is shown in Figure 1.

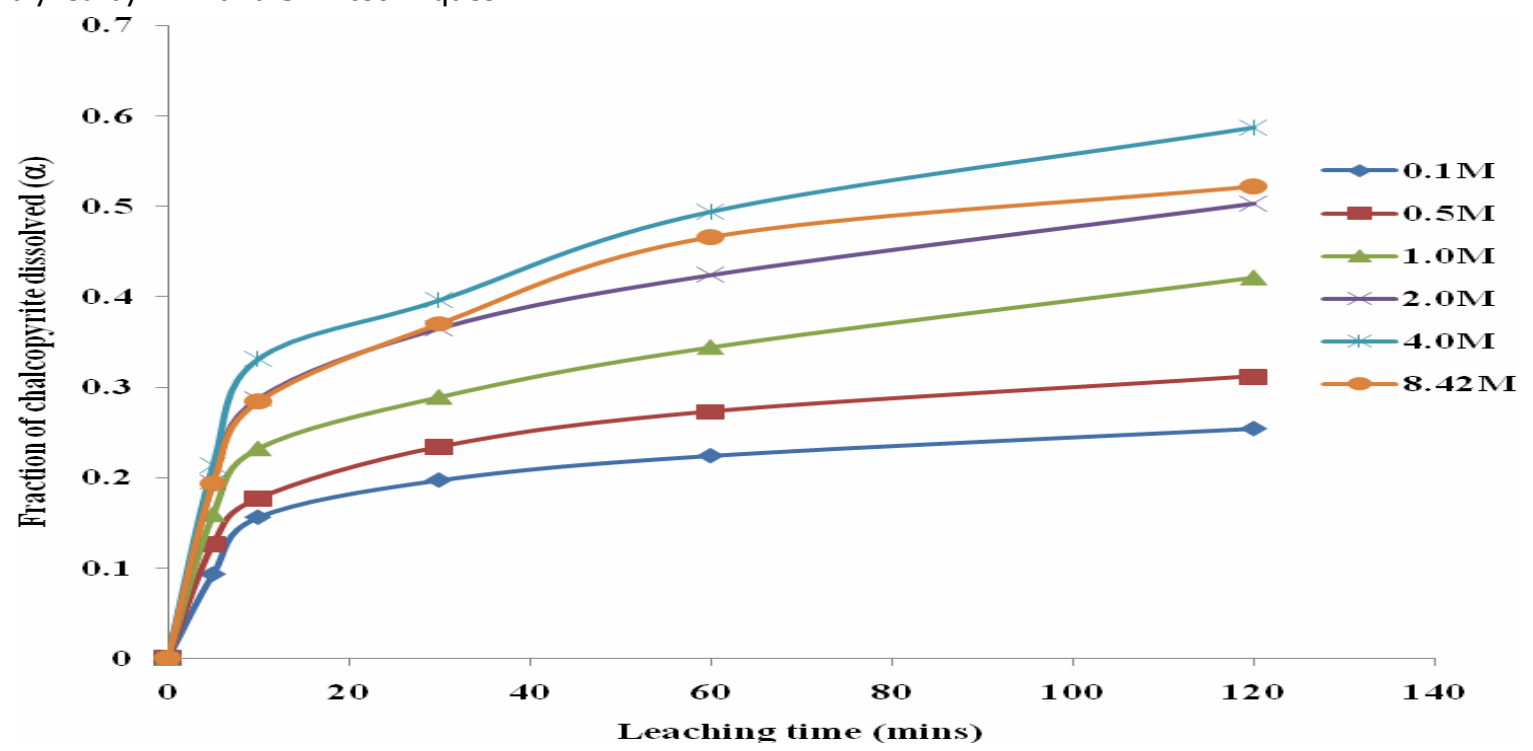

Figure 1: Effect of $\mathrm{HNO}_{3}$ concentration on chalcopyrite ore dissolution.

As shown in Figure 1, the chalcopyrite dissolution increases gradually with leaching time and with increase in $\mathrm{HNO}_{3}$ concentration. This result indicates that chalcopyrite dissolution is controlled by the hydrogen ion $\left[\mathrm{H}^{+}\right]$concentration in the solution. It is important to note that the extent of increasing ore dissolution by $\mathrm{HNO}_{3}$ as leachant could apparently be as a result of high oxidizing power of the leachant (Liu et al. 2010).

The effect of temperature on the rate of chalcopyrite ore dissolution was investigated using temperature range $27^{\circ} \mathrm{C}-80^{\circ} \mathrm{C}$ by $4 \mathrm{M} \mathrm{HNO}_{3}$ solution. The result of this investigated is presented in Figure 2. 


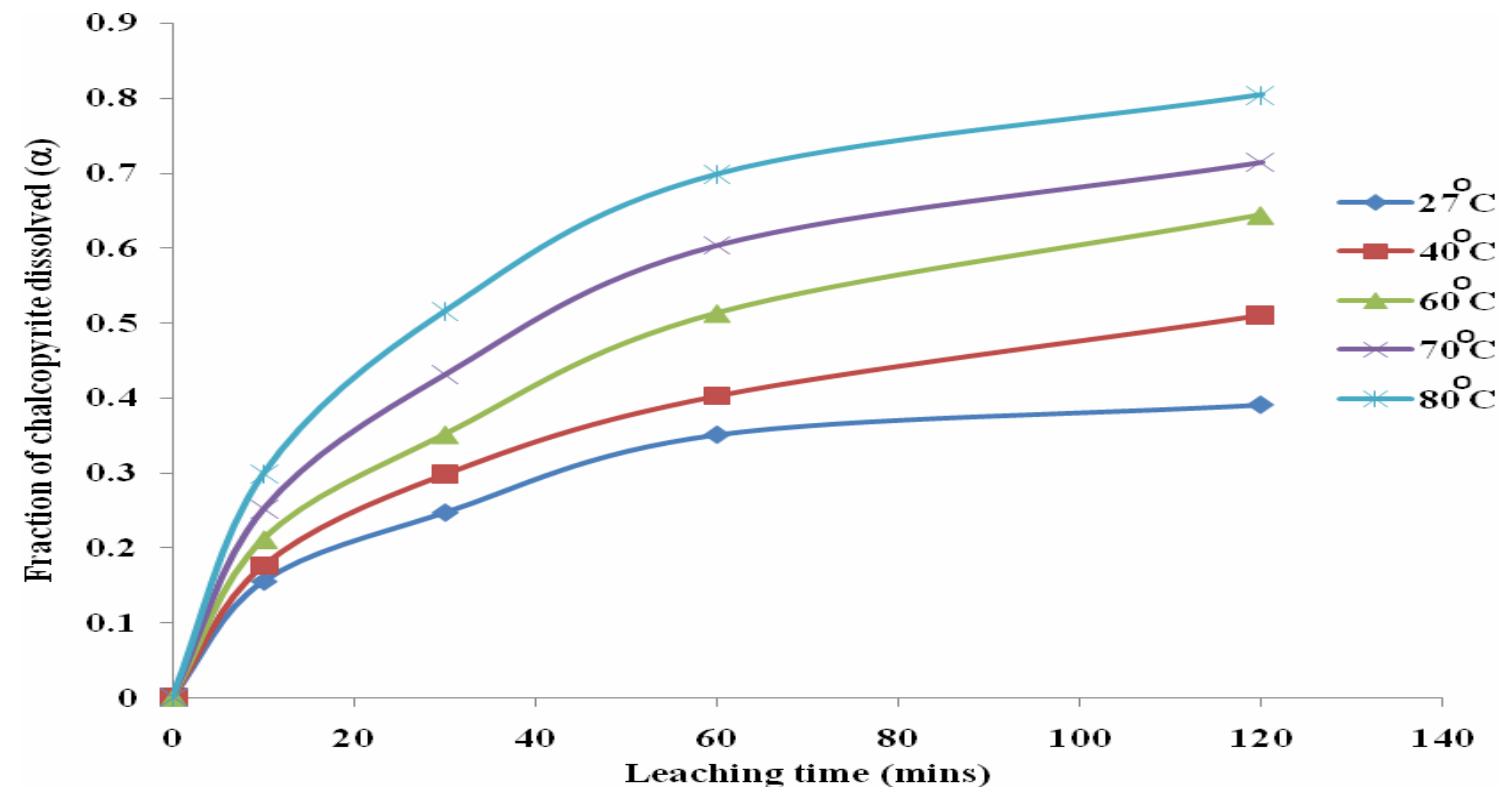

Figure 2 Effect of temperature on chalcopyrite leaching by $4 \mathrm{M} \mathrm{HNO}_{3}$ solution.

From the result in Figure 2, it is observed that increasing the temperature is accompanied by increase in chalcopyrite dissolution rate. At $80^{\circ} \mathrm{C}$, for of acid solution through evaporation (Baba et al. 2009; Olanipekun, 1999).

The effect of particle size on the dissolution example, about $80.5 \%$ of chalcopyrite ore was dissolved within 120 minutes. The result of other similar studies showed that chalcopyrite mineral is very active at high temperature, and the dissolution rate of the ore will be increased (Abouzeid, 1990). Though, in this study, the reaction temperature was particularly limited to $80^{\circ} \mathrm{C}$ because of significant loss of chalcopyrite ore by $4 \mathrm{M} \mathrm{HNO}_{3}$ solution at $80^{\circ} \mathrm{C}$ was examined using three particle sizes: $-90+75 \mu \mathrm{m}$, $112+90 \mu \mathrm{m}$, and $-300+112 \mu \mathrm{m}$. The result of this investigation is shown in Figure 3.

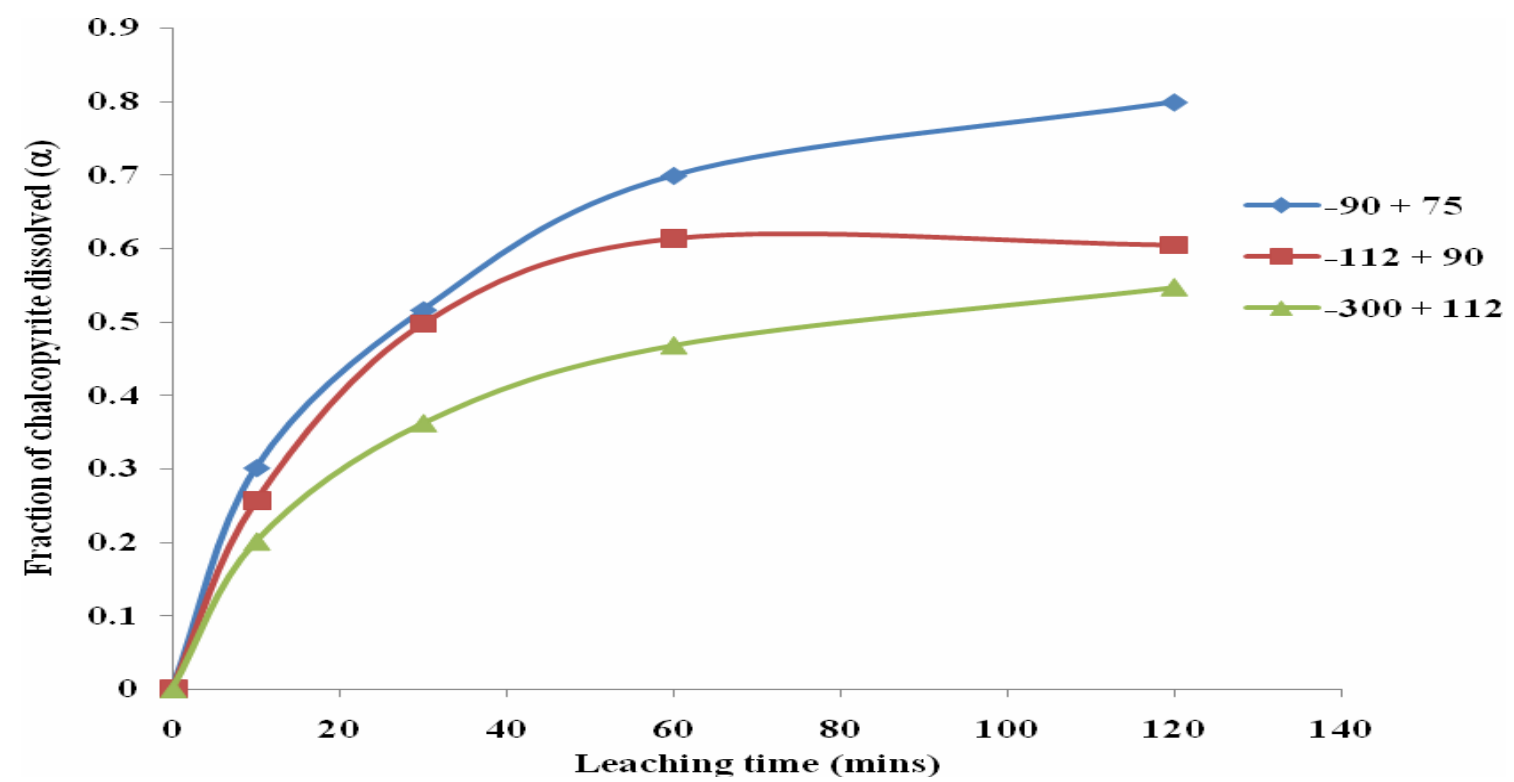

Figure 3: Effect of particle size on nitric acid chalcopyrite dissolution at various leaching time.

From Figure 3, while the dissolution of chalcopyrite with the samples of particle size $-90+75 \mu \mathrm{m}$ was between $30-80 \%$ after 120 minutes, the dissolution decreased to about 20 - 55\% for the particle size above $-90+75 \mu \mathrm{m}$. This may be attributed to increase in surface area for the finer size chalcopyrite ore (Baba et al. 2012; Baba et al. 2007; Aydogan et al. 2005).

\section{DISCUSSION}

Due to reduction in both the mass of solid and the particle size during leaching, the shrinking particle model is always applied to describe the leaching kinetics (Fabiano et al. 2010; Levenspiel 1972). Consequently, the dissolution mechanism of chalcopyrite ore is based on three main kinetic models. 
These are the diffusion, surface reaction and the mixed kinetic model containing diffusion and surface reactions, which takes place simultaneously (Aydogan et al. 2005). If the reaction rate is controlled by diffusion through a product layer, the integrated rate equation (1) holds (Aydogan et al. 2005; Sohn and Wahworth 1979). Apparently, if the reaction is controlled by a surface reaction, then equation (2) is applicable.

$$
\begin{aligned}
& 1-\frac{2}{3} \alpha-(1-\alpha)^{2 / 3}=\frac{K_{C} M_{B} C_{A} t}{\rho_{b} a r_{0}}=K_{d} t \\
& 1-(1-\alpha)^{1 / 3}=\frac{K_{C} M_{B} C_{A} t}{\rho_{b} a r_{0}}=K_{r} t
\end{aligned}
$$

where $\mathrm{a}$ is the fraction reacted, $\mathrm{K}_{\mathrm{c}}$ is the kinetic constant, $M_{B}$ is the molecular weight of the solid, $C_{A}$ is the concentration of the dissolved lixiviant, $A$ is the bulk of the solution, $a$ is the stoichiometric coefficient of the reagent in the leaching reaction, $r_{0}$ is the initial radius of the solid particle, $t$ is the reaction time, $D$ is the diffusion coefficient in the porous product layer, $\rho_{b}$ is density of the solid and $K_{d}$ and $K_{s}$ are rate constants (Ayinla, 2012; Baba et al. 2012, 2013; Baba and Adekola, 2010; Fabiano et al. 2010).

It was observed that of the two tested models, the one of equation (1) fitted all data expressed in Figs. $1-3$. According to equation (1), a plot of $1-2 / 3 a-(1-a)^{2 / 3}$ versus leaching time is a straight line with slope $K_{d}$ when the process is diffusion controlled mechanism as shown in Figure 4.

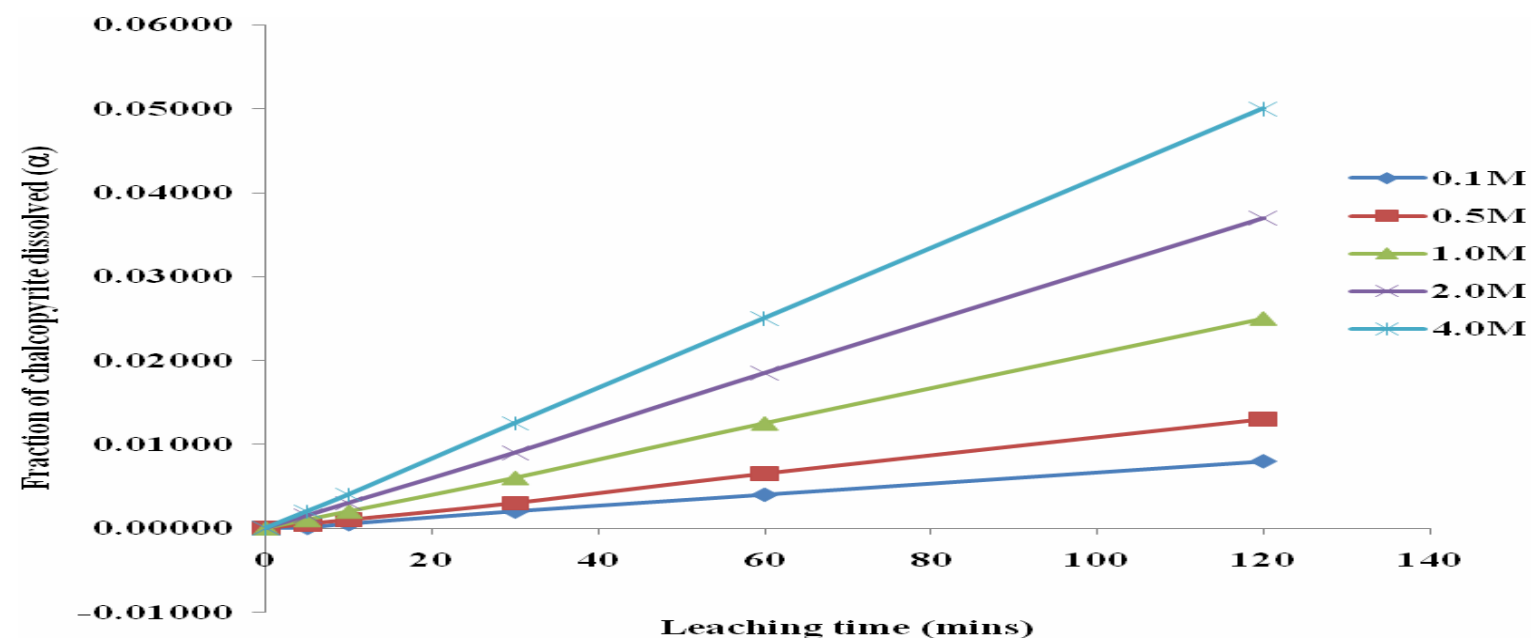

Figure 4: Plot of $1-\frac{2}{3} \alpha-(1-\alpha)^{2 / 3}$ versus leaching time at different $\mathrm{HNO}_{3}$ concentration.

Hence, the experimental rate constants, $K_{d}$, were evaluated from the slope of Figure 4. These values were used to plot $\ln \mathrm{K}_{\mathrm{d}}$ versus $\ln \left[\mathrm{HNO}_{3}\right]$, as shown in figure 5 .

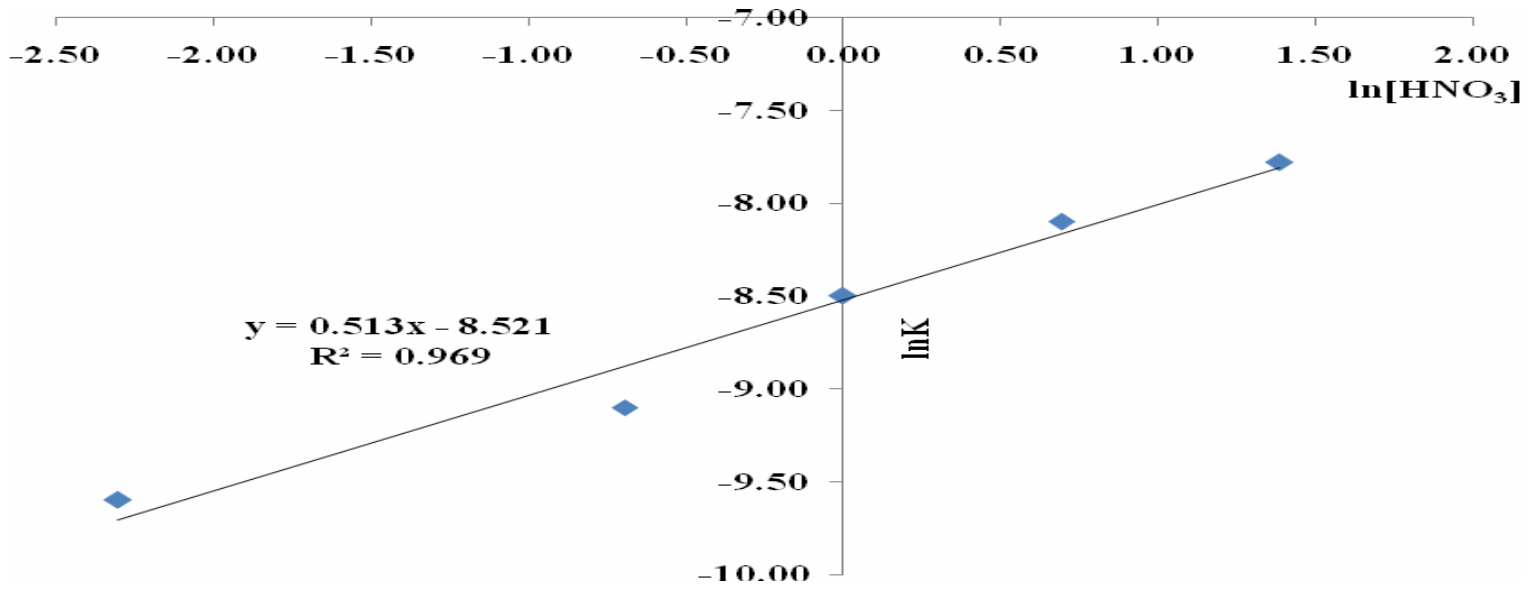

Figure 5: Plot of InK versus $\operatorname{In}\left[\mathrm{HNO}_{3}\right]$ 
From the result in Figure 5, the slope of the straight line graph was calculated to be 0.51 . This indicates that the reaction order is half order with respect to $\mathrm{HNO}_{3}$ leaching for which its concentration $\leq 4 \mathrm{M}$.

However, from the result in Figure 3, the linearity of the data gave a result as presented in Figure 6.

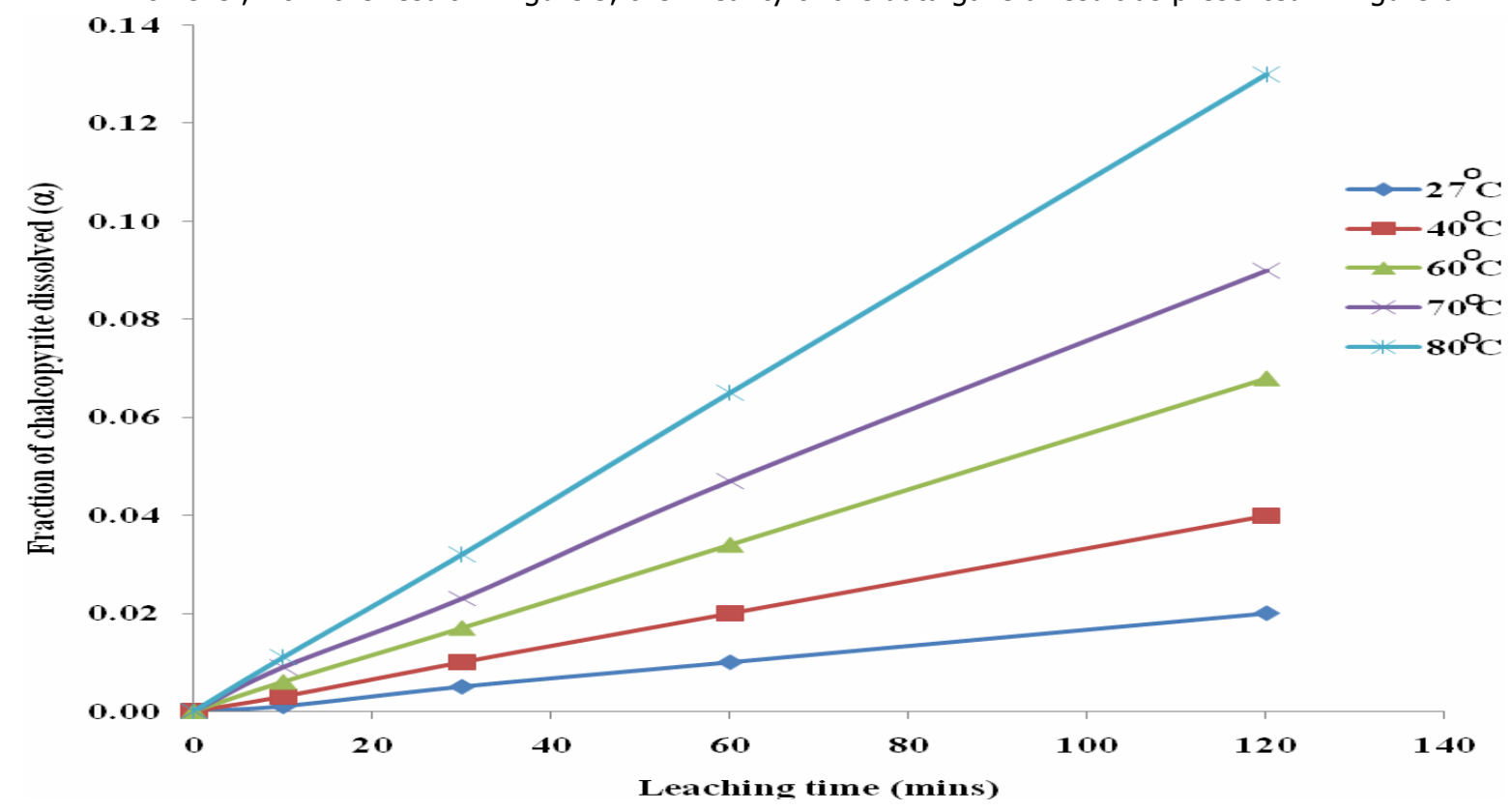

Figure 6: Plot of $1-\frac{2}{3} \alpha-(1-\alpha)^{2 / 3}$ versus leaching time at different temperature

The apparent rate constants $K_{d}$ were determined from the slopes of the straight lines in Figure 6 and were used to plot Arrhenius plot of Figure 7.

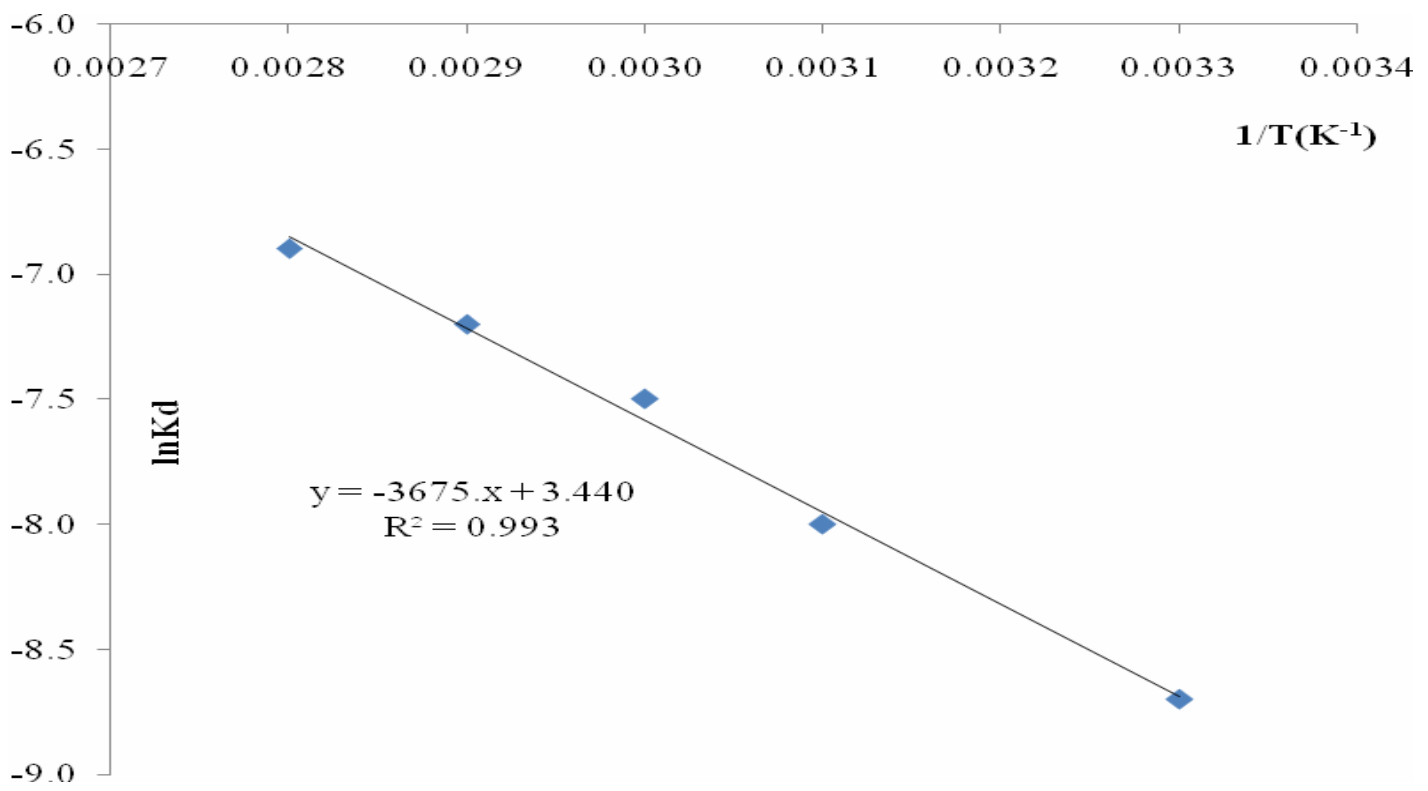

\section{Figure 7: Plot of InK $K_{d}$ versus 1/T.}

Figure 8 shows the Arrhenius plot, $\ln K_{d}$ against the reciprocal of reaction temperature, from which the activation energy was calculated to be $29.93 \mathrm{kJmol}^{-1}$. The value suggests that the mechanism of dissolution via $\mathrm{HNO}_{3}$ occurs through a diffusion control route.

To further support this assertion, the plot of the rate constant, $\mathrm{K}$, versus inverse of square of particle radii $\left(1 / r_{0}\right)^{2}$ on the particle diameter gave a linear relationship as presented in Figure 8. Hence, linearity of the plot in Figure 8 affirmed the rate determining step for the dissolution of chalcopyrite ore by $\mathrm{HNO}_{3}$ media occur via diffusion control mechanism. Apparently, the plot of $K$ versus $\left(1 / r_{0}\right)$ was not linear. 


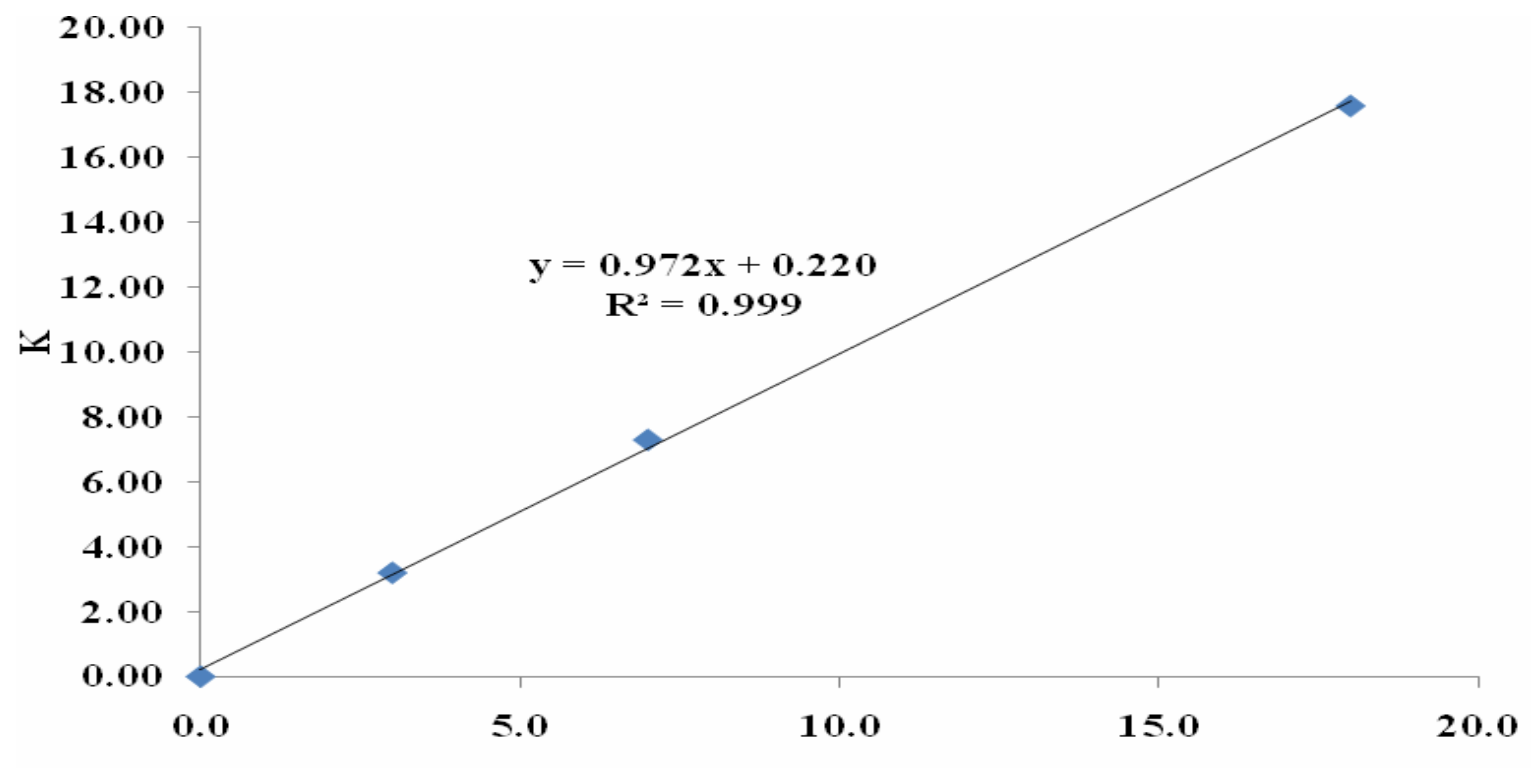

Figure 8: Plot of $K$ versus $\left(1 / r_{0}\right)^{2}$

$(1 / \mathbf{1 0}) 2$

The X-ray diffraction analysis of the solid residual product obtained from the leaching of $10 \mathrm{~g} / \mathrm{L}$ chalcopyrite ore at optimal condition by $4 \mathrm{M} \mathrm{HNO}_{3}$ at $80^{\circ} \mathrm{C}$ are presented in Table 1.

Table 1: Retained peaks after optimal leaching

\begin{tabular}{|lrlc|}
\hline 2-theta (deg) & $\begin{array}{l}\mathrm{O} \\
\text { d= } \mathrm{A}\end{array}$ & Compound & JCPDS File Number \\
\hline 49.9150 & 1.8256 & a-quartz $\left(\mathrm{SiO}_{2}\right)$ & $05-0490$ \\
7.7162 & 1.5959 & Tin oxide $\left(\mathrm{SnO}_{2}\right)$ & $13-0111$ \\
\hline
\end{tabular}

Table 1 showed that the predominant peaks in the chalcopyrite ore $\left(\mathrm{CuFeS}_{2}\right)$, namely pyrite $\left(\mathrm{FeS}_{2}\right)$ and host of other iron compounds in the original sample were effectively leached at optimal conditions. However, the dominant mineral phases that formed the residual products are a-quartz $\left(\mathrm{SiO}_{2}\right)$ and tin oxide $\left(\mathrm{SnO}_{2}\right)$. Further investigation of change on chalcopyrite surface at $80^{\circ} \mathrm{C}$ by $4 \mathrm{M} \mathrm{HNO}_{3}$ solution during leaching for 2 hours was also examined by SEM as depicted in figure 9.

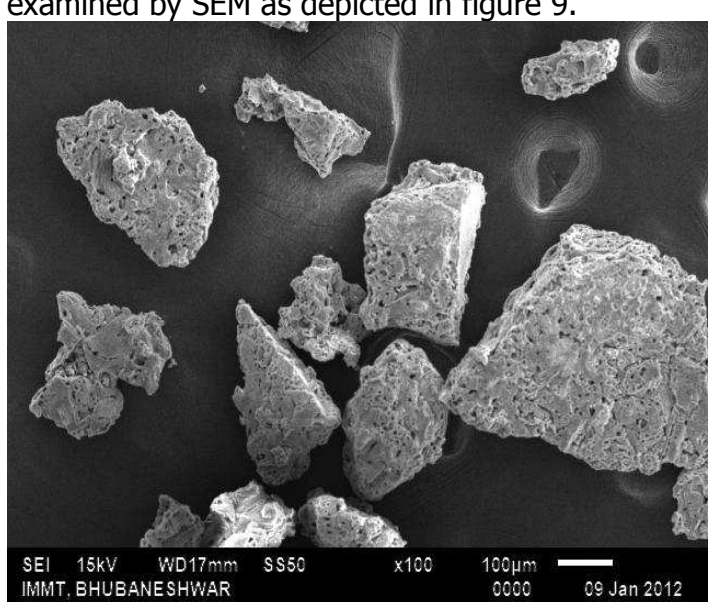

(a)

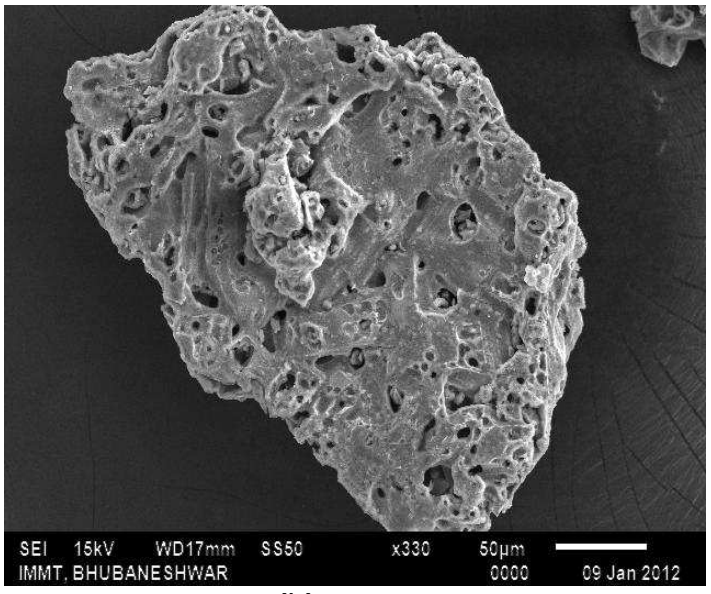

(b)

Figure 9: SEM Micrograph of leaching residue of chalcopyrite ore by $4 \mathrm{M} \mathrm{HNO}_{3}$ at $80^{\circ} \mathrm{C}$

(a) Image of leaching residue at $60 \mathrm{~min}$ (about $70 \%$ dissolution)

(b) Image of leaching residue at $120 \mathrm{~min}$ (about $81 \%$ dissolution)

From SEM in figure 9, it is evident that a greater reduction in the phase of the ore (b) comparing with the SEM of leaching at 60 minutes (a) based on the larger pore size observed. Furthermore, it is worthwhile to predict that the possible presence of pyrite on the surface of the ore may gave rise to sulphur layer formation, because of high copper recovery and may prevent the leaching of chalcopyrite ore. Therefore, the possible presence of pyrite (when unleached) may leads to greater permeability and the porosity of the sulphur layer formed which apparently may enhances chalcopyrite leaching (Javad-Koleini et al. 2010). 


\section{CONCLUSION}

Based on the results established from the present study, it was found that leaching by $4 \mathrm{M} \mathrm{HNO}_{3}$ solution using $10 \mathrm{~g} / \mathrm{L}$ of $-90+75 \mu \mathrm{m}$ particle size within 120 minutes by moderate stirring, the extent of the chalcopyrite ore reached $81.46 \%$. Also, the reaction rate increases with increasing $\mathrm{HNO}_{3}$ concentration, reaction temperature, and decrease in particle size. The result of dissolution study has been analyzed using shrinking core model and found that the reaction rate is controlled by diffusion of copper through the porous product layer. To this end, the reaction order with respect to $\mathrm{HNO}_{3}$ concentration was found to be 0.51 . The activation energy $\mathrm{Ea}$, and

\section{REFERENCES}

Abouzeid, M., (1990): Mineral processing laboratory manual, Trans Tech. Publication, Cairo, Egypt, 5-15.

Aydogan, S., Aras, A., Canbazoglu, M., (2005): Dissolution Kinetic of sphalerite in acidic ferric sulphuric acid, Hydrometallurgy, 46, 71-83.

Ayinla, I. K., (2012): Dissolution kinetics and solvent extraction of copper from Chalcopyrite ore in acidic media. M.Sc Thesis, Department of Chemistry, University of Ilorin, Ilorin, Nigeria, $1-166$.

Baba, A. A., Adekola, F. A., (2010): Hydrometallurgical processing of a Nigerian sphalerite in hydrochloric acid: Characterization and dissolution kinetics, Hydrometallurgy, 101, 69-75.

Baba, A. A., Adekola, F. A., Toye, E. E., Bale, R. B., (2009): Dissolution kinetics and leaching of Rutile ore in hydrochloric acid. J. Min. and Mat. Charact. and Engr., 8(10), 787-801.

Baba, A. A., Adekola, F. A. Dele-Ige, O. I., Bale, R. B., (2007): Investigation of dissolution kinetics of a Nigerian Tantalite ore in Nitric acid, $J$. Min. and Mat. Charact. and Engr., 7(1), 8395.

Baba, A. A., Ayinla, I. K., Adekola, F. A. Ghosh, M.. K., Bale, R. B, Sheik A.R, Alabi, A. G. F. (2012): Ferric chloride leaching of a Nigerian chalcopyrite ore. Science Focus, 11(2), 199187.

Baba, A. A., Ayinla, I. K., Adekola, F. A. Bale, R., B., Ghosh, M. K., Alabi, A. G. F., Sheik, A.R, Folorunsho, I. O., (2013): Hydrometallurgical application for treating a Nigerian chalcopyrite ore in chloride medium. Part I: Dissolution kinetics assessment. Int. J. Miner. Metall. \& Mat., 20(11), 1-8.

Fabiano, M. F., Santos, P. S., Rodrigo P., Victor, A. O., Carlos, A. S., Versiane, A. L., (2010): The kinetic of zinc silicate leaching in sodium hydroxide. Hydrometallurgy, 102, 43-49.

Ghosh, A., Ray, H. S. (1991): Principles of extractive metallurgy, $2^{\text {nd }}$ ed. Wiley Eastern Ltd, New Delhi.
Arrhenius constant (on plotting Figure 7 from the origin) gave $29.93 \mathrm{kJmol}^{-1}$ and $3.44 \times 10^{3} \mathrm{~s}^{-1}$, respectively for the dissolution process. Finally, analysis of the residual product by X-ray diffraction data showed that about $19 \%$ of the initial solid material that form undissolved materials contained aquatz $\left(\mathrm{a}-\mathrm{SiO}_{2}\right)$ and Tin oxide $\left(\mathrm{SnO}_{2}\right)$.

\section{Acknowledgement}

One of the authors: Ayinla K. I. wishes to thank the Institute of Minerals and Materials Technology, Bhubaneswar-751013, India for kind assistance in SEM analysis.

Habashi, F. (2002): Clean Technology in the metallurgical industries in proc intern. Conf. on metallurgical high technology and New materials of heavy non-ferrous metals, Kunmming China.,521-531.

Ikiz, D., Gulfen, M., Aydin, A. O., (2006): Dissolution kinetics of primary chalcopyrite ore in hydrochloric solution, Miner. Eng., 19, 972981.

Javad-Koleini, S. M., Jafarian, M., Abdollahy M., Aghazadeh, J., (2010): Galvanic leaching of chalcopyrite in atmospheric preseure and sulphate media: Kinetic and surface studies. Ind. Eng. Chem, Res., 4a, 5997-6002.

Levenspiel, O. (1972): Chemical Reaction Engineering John Wiley and Son, New York, 578.

Liu, W., Tamg, M., Tang, C., He, J., Yong, S., Yong, J, (2010): Dissolution Kinetic of low grade complex copper ore in ammonia-ammonium chloride solution. Trans. Non-ferrous Met. Soc., China, 20, 910-917.

Louise, W. (2008): Mining for mineral fuel can go conflicts. Yahoo News Associated Press, Yahoo.inc, Retrieved on 01/11/2008.

McGraw-Hill (1987): Encylopedia of Science and Technology, Vol. 10, $8^{\text {th }}$ ed., Toronto, Tokyo, $450-452$.

Olanipekun E.O. (1999): A Kinetic study of the leaching of a Nigeria Ilmenite ore by hydrochloric acid. Hydrometallurgy, 53, 1-10

Olubambi, P. A., Borode, J. O., Ndlovu, S. (2006): Sulphuric acid leaching of zinc and copper from Nigeria complex sulphide ore in the presence of hydrogen peroxide Journal of the Southern African Inst. of Min. and Metal., 106, $765-770$.

Rotuska, K., Chmielewski, T. (2008): Growing role of solvent extraction in copper ores processing, Physicochem. Probl. Miner. Proces., 42, 2936.

Sohn, H. Y., Wahsworth, M. E. (1979): Rate process in extractive metallurgy, Plenium, New York $2^{\text {nd }}$ ed. 120-126.

Szymanowski, J., (1996): Copper hydrometallurgy and extraction from chloride media, Journal of Radio-Analytical and Nuclear Chemistry, 28(1), 183-194. 